\title{
Globalization, Immigration, and the Gender Implications of Not Just Numbers in Canada
}

\author{
Jennifer Hyndman
}

\begin{abstract}
The immigration of refugees to Canada has always been gendered. Today, the majority of refugees to this country continue to be male, while family class immigrants are more often female. Social integration and labour market participation uponarrival also vary tremendously by gender, among other factors. The recent Legislative Review, entitled Not Just Numbers, has important gender implications for future immigration to Canada. The author argues that the proposals outlined promote economic selfsufficiency and global competitiveness as the basis for future immigration, refugees being the sole exception. The Review is analyzed in relation to Saskia Sassen's workon globalization, immigration, and the "new geography of power." The gendered implications of the Review's proposals arediscussed with specific reference to refugees, domestic caregivers, and family class immigrants.
\end{abstract}

\section{Précis}

L'immigration de réfugiés vers le Canada a toujours impliqué une nette dimension de sexage. Encore aujburd'hui, la majoritédes réfugiés dece pays sont de sexe masculin, alors que les imonigrants de la catégorie de la famille sont plus souvent des femmes. L'intégration sociale et la participation au marché $d u$ travail à l'arrivée varie aussi très fortement, fonction de plusieursfacteurs, dont le sexage. Le récent rapport législatif, intitulé Au-delà des chiffres a de nombreuses implications en terme de sexage pour l'immigration future an Canada. Lesauteurs présentent ici une argumentation selon laquelle les propositions mises de l'avant dans ce rapport législa-

Jennifer Hyndman, Ph.D., is Assistant Professor in the Department of Social and Behavioural Sciences, Arizona State University, West Campus, Phoenix, AZ, USA. tiffont la promotion de l'autonomieéconomique et de la compétitivité globale comme fondement de l'immigration future, exception strictement faite des réfugiés. Le rapport est analysé ici à la lumière des travaux de Saskia Sassen sur la globalisation, l'immigration, et la "nouvelle géographie du pouvoir». Les implications sur le sexage des propositions du rapport sont discutées avec référence spécifiqueaux réfugiés, aux tuteurs domestiques, et aux immigrants dans la catégorie de la famille.

We consider the effect of the global economy on Canada's economic immigration. Our policy model ... maximizes long-term potential benefits for Canada while minimizing any short-term costs ... (Executive Summary, Not Just Numbers, 3)

Who fits best and costs least? This is the spirit of the Immigration Legislative Review, entitled Not Just Numbers, commissioned by the minister of Citizenship and Immigration Canada, and released in January 1998. In this brief paper, I analyze the gender implications of the Review's recommendations across the immigrant/refugee distinction. I argue specifically that the proposal, which suggests separate legislation for immigrants and refugees, also creates the basis for a feminized protection act to assist refugees at a distance and a gender-blind, self-supporting system for all other groups of immigrants. Furthermore, I draw on but amend Saskia Sassen's analysis of immigration as one of the last remaining spaces of sovereign power in the context of an increasingly globalizing economy, arguing that the Immigration Legislative Review in fact proposes to fine-tune Canadian immigration policy to promote freer trade in high end immigrants. Citing the report, "[g]lobalization is the code word for the breakdown of traditional boundaries among sovereign nations, economic markets and individuals" (chapter 1,
1.4). The Review advocates recruitment of "modern pioneers" as its self-supporting immigrants, pushing for welleducated, employable candidates who are competent in either English or French. Diversity in culture, class, and source countries, as well as a gender balance, will be more elusive should these proposals be accepted, but the economy should prosper. As Saskia Sassen notes, "[w]hat matters here is that global capital has made claims on national states, which have responded through the production of new forms of legality." ${ }^{1}$ In this case, new legislation has yet to be implemented, a fact which provides the impetus for this paper and a basis for discussion as well as action.

\section{Background on the Review}

The Review acknowled ges lack of attention to gender. The authors state that

[i]n the time available, we were unfortunately unable systematically to check the effect of our recommendations on equality between the sexes. Citizenship and Immigration Canada should undertake such an analysis before formulating its policy, revising the Act and Regulations and establishing its programs. (Chapter 9, 126)

Gender is conspicuously and admittedly absent.

The Review proposes the separation of immigration and refugee legislation. It also argues for the combination of the immigration and citizenship acts, arguing that these latter pieces of legislation are part of continuum (recommendations 1 and 2). Apparently refugees are not part of the citizenship trajectory, and this is reflected in recommendation 5 of the Review in which people are barely mentioned in the objectives:

The Objectives of the Protection legislation should be to: a) Enable Canada to take leadership in the international community ...; b) Fulfil 
our domestic obligations with respect to international humanitarian and human rights law; and c) Uphold our obligations by ensuring that we extend protection only to those who require and deserve it.

In contrast, the first objective of the immigration and citizenship legislation is to

Facilitate the entry, whether temporary or permanent, of those persons whowill contribute to Canada's prosperity and to the economic well-being of Canadians. (recommendation 4)

The implication of this is that Canada is obliged to protect refugees, but they will not seriously contribute the economic prosperity of this country.

\section{Directions for the Current Immigration and Refugee Situation}

Amajor and controversial feature of the report is a proposed official language requirement. In 1996, 41 percent of Canada's 224,000 newcomers spoke neither French nor English. ${ }^{2}$ Counting official language competence as a criterion for prospective self-supporting immigrants would have a gendered impact. The Canadian Council for Refugees notes that

[f]actors such as official language skills, professional experience and education are all [currently] taken into account, to the disadvantage of refugee women who have less opportunity than men to acquire these skills and experiences. In addition, single women with children are often found to be unlikely to successfully establish. ${ }^{3}$

Women's access to language training, it should be added, is generally less than that of men due to family responsibilities, societal norms, and economic circumstance.

During the 1997-98 fiscal year, the Federal Government paid Ontario $\$ 95.6$ million for adult language instruction; the cost to Ontario for children's language instruction was $\$ 236.2$ million. 4 These figures point to the impetus for ensuring linguistic competence in English or French. While Ontario receives
54 percent of all new immigrants, 5 the Ontario government plans a drastic reduction in financing for adult education. ${ }^{6}$ At the same time as provinces want the Federal Government to pay more of the English as a Second Language (ESL) instruction, especially for children who fall under provincial jl:risdiction, the Federal Government wants to reduce its spending, not add to it. The authors of the Review acknowledge one trend that influenced their report: "'tax fatigue,' deficits and debt have imposed severe financial constraints on governments" (chapter 1, 1.5). Starting from this assumption, immigrants should pay for themselvesat the very least.

\section{Separate and Unequal: Immigrants and Refugees in the New Canadian Order}

If the recommendations of the ILR were adopted, a two-tier stream of immigration would emerge: on the onehand, a gender-blind stream of employable, well-educated, and linguistically competent immigrants and their families; and on the other, a very different refugee stream of newcomers whose "ability to establish" is nolonger a question. There are already major differences and inequalities between landed immigrants on the basis of immigrant class, but the changes proposed by the ILR would exacerbate these considerably. Just as Nancy Fraser has argued that social assistance is a more feminized stream of government assistance than (un)employment insurance which serves the formerly employed in a given economy, ${ }^{7}$ so too would the refugee stream bemore feminized and marginal to the economy than non-refugee immigrants. The Review argues that in order to assist the mostneedy, namely women and children, the "ability to establish" criteria should be dropped. "... Canada can focus on assisting the most vulnerable, overwhelmingly women and children, as close as possible to their home country" (recommendation 88). The assumption that women and children are more needy than men is not proven, nor is the assumption that the most needy (read: most worthy) refugees requiring resettlement are located close to their home country where violence or threat of persecution has occurred, rather than at a port of entry in Canada. The implication is that many refugees who arrive at Canadian borders are fraudulent, and while there is no doubt some truth to this, no evidence is presented or case made. ${ }^{8}$ Instead, it is assumed that gen. der is a constant defining quality of bona fide refugee status, a prenise which is problematic in international refugee law.

Of the proposed Protection Act, the Office of the United N.dtions High Commissioner for Refugees (UNHCR) states succinctly, "[t]oo little independence, not enough flexibility, flawed assumptions." 9 The UNHCR is particularly concerned that the inland refugee determination process would lose its quasijudicial independence, if handed over to departmental bureaucrats. The "underlying assumption may be that persons seeking protection overseas are more in need than asylum seekers who arrive directly in Canada," said the UNHCR commission; "[i]f so, UNHCR would respectfully disagree." The hierarchy of need for asylum outlined in the Review is not codified in law nor supported in refugee policy. It represents, in my view, a political decision driven by neo-liberal economics.

Another important observation relates to the geographical "spacing" implied in this and other recommendations. The most needy refugees, assumed to be women and children, should be assisted as close to their home countries as possible. This attests to a preference to manage the refugee problem "over there," rather than provide resettlement places "over here" in Canada. This vindicates a trend identified by refugee scholars: as states nominally respect their international obligations in refugee law but reduce their resettlement numbers, they have increased financial contributions to multilateral organizations-like the United Nations High Commissioner for Refugees (UNHCR) - in order to manage "the refugee" problem far away from their own borders. ${ }^{10}$ Canada and the United States are perfect examples. This 
begs the rather obvious question, "protection for whom" - refugees or Canadian borders? ${ }^{11}$

Wenona Giles contends that refugees are spatially and institutionally divided on the basis of gender. She presents evidence to illustrate that the small group of refugees resettled in Canada is biased towards men, and that refugee women and children tend to be helped in a different way and in a different placethrough international aid, generally in camps adjacent to their home countries. ${ }^{12}$ Using this gendered socio-political map as a heuristic tool, the ILR proposes shifting emphasis from current refugee resettlement to Canada to refugee women and children abroad. While this proposition may sound more gender-sensitive, it is a defensive and rhetorical move to maintain "the refugee problem" at a distance. As Rosalyn Kunin, co-author of the ILR, states,

we have no obligation, no legal obligation to protect refugees who are not in Canada. But Canada is a rich and a compassionate country ... we certainly can solve problems for some refugees abroad. ${ }^{13}$

To assist refugees abroad is to prevent them from becoming legalobligations to the Government of Canada in Canada under international refugee law.

The ILR recommends that " $t$ ] he Protection Act should enable Canada to exercise leadership in generating international protection-oriented responses to refugee crises" (recommendation 82). While suitably vague, this recommendation says nothing to suggest that Canada should even maintain its current refugee resettlement numbers. In fact, the executive summary (p.4) states that

Canada should take a position of leadership in developing new models for international responsibility sharing in the identification and resettlement of those in need of protection ... Until such time as those international models are developed and operational, Canada should reinvigorate its commitment to the displaced and persecuted.

The implication here is that Canada should be part of an effort to deal with refugees in some othermanner, but until then the status quo should be maintained.

The target of government-sponsored (or CR-1) refugees in Canada has remained constant at 7,300 for the last four years. In real terms, however, the numbers have fallen because the Government has folded various special groups and programs into this number as the years progressed. Although there is a commitment in the Review to screening more refugees overseas (or at least close the source), there is no mention of increasing the numbers of refugees selected there. In fact, numbers suggest that a reduction is already underway. Statistics for 1997 illustrate the permanent residence (or landed immigrant status) was granted to 7,712 government-assisted refugees, 2,658 privately sponsored refugees, and 10,624 refugee claimants through the inland determination system. ${ }^{14}$ The number of privately sponsored refugees $(2,658)$ is the lowest for this category since the beginning of the program in 1979. The combination of private and government-sponsored refugees selected overseas (the proposed groups of choice under the ILR) amounts to 10,370 , also the lowest number for these categories taken together since 1979. Finally, because the number of inland cases authorized for permanent residence is so much lower than governmentestimates of $14,000-18,000$, one can surmise that approval rates for refugee claimants who apply at a Canadian port of entry have fallen.

Thereis also little evidence to suggest that the political will to increase resources required to increase numbers either here or in the United States (see table 1).

Decreases in Canadian refugee resettlementare not as marked as those in the
United States. Nonetheless, the United States accepted a much greater proportion of the refugee burden than did Canada earlier in the decade. A positive development outlined in the ILR is the expansion of the definition of refugee to include evolving human rights norms. This proposal is a good one, but rhetorical if there is no commitment to allow resettlement numbers to reflect an expanded definition and therefore potentially expanded need.

Saskia Sassen argues that "economic globalization denationalizes national economies; in contrast, immigration is renationalizing politics. ${ }^{16}$ Speaking of the United States, she provides evidence that these two processes are simultaneously underway. However, her comments need to be amended in the Canadian context because of a major geographical difference between the two countries, namely, the 2000 mile U.S. border with Mexico and, in practice, with much of Central America. This southern border provides the focus of attention for United States authorities, given the current tide of migrant workers-both documented and undocumented-from further south. Canada is the more controlled position of having only one land border with the United States. One can argue, then, that economic globalization in the Review is most closely connected with immigration policy and government "choice" of newcomers. The proposed Protection Act, by contrast, is an expression of national sovereignty and well-beingan effort to "renationalize politics" by attempting to help refugees near the source of the problem, rather than in Canada. "There is," says Sassen, "a combination of drives to create borderfree economic spaces yet intensify border control to keep immigrants and refugees out." ${ }^{17}$ In the case of Canada,

Table $\mathbf{1}^{15}$

Annual Resettlement Ceilings for Government-Sponsored Refugees

\begin{tabular}{lrrrrr}
\hline & $1992 / 93$ & $1993 / 94$ & $1994 / 95$ & $1995 / 96$ & $1996 / 97$ \\
\hline USA & 142,000 & 121,000 & 110,000 & 90,000 & 78,000 \\
Canada & 13,000 & 11,000 & 7,300 & 7,300 & 7,300 \\
\hline
\end{tabular}


the ILR implies that it is refugee claimants who must be kept out. All othersimmigrants and refugees selected overseas-would be technically controlled by the government. The proposed separate legislation and major distinctions in selection criteria for refugee and immigrantmigration moves the direction of Canadian immigration towards greater segregation and ghettoization between the refugee stream of immigrants and the self-supporting newcomers.

\section{Going Global: Harmonization of Immigration \& Global Economic Integration}

One can argue that the best immigrants are those that can integrate well and contribute financially to the prosperity of the country-a difficultclaim to counter. When economic productivity prevails as the defining criteria, however, other characteristics such as social class and cultural background are at risk of becoming less diverse. One of the most progressive exceptions to this scenario in the Review is the expansion of the definition of "family" to include common-law and same-sex couples. While this is a welcome move, it seems to be the exception to the proposed rules outlined in the Review.

Combining immigration and citizenship in one act, the ILR proposes that citizenship standards rise to include "active participation" in Canadian society. Recommendation 31 outlines proposed criteria for citizenship which would include, among other things, active participation in at least two of the following: employment, study, volunteer/community service, and family care. The Canadian Council for Refugees has noted that these criteria discriminate against family care-givers, usually women, who "are often fully occupied in the home and do not have opportunity to qualify for one of the other 3 categories." 18 Existing patterns of gendered participation in overseas study, the workplace, and the voluntary sector are seemingly ignored.

These criteria of active participation are particularly troubling for domestic care-givers from abroad who currently provide affordable child care and domestic work to Canadian households. I have serious reservations about the substandard terms of employment outlined by the government for these migrant workers who can apply for landed immigrant status after two years work in Canada. I am more perturbed, however, by the idea that these women might be excluded altogether from permanent residence and citizenship. Many of the domestic workers from the Philippines are highly qualified as accredited teachers, nurses, accountants in their own countries. ${ }^{19}$ However, it is likelybased on the ILR - that they would no longerbeeligible for permanent resident status and citizenship. Their education and qualifications would not be applicable to their offer of employment in Canada, which is a requirement for immigrant skilled workers. ${ }^{20}$ Therefore, they would be considered only for proposed "Foreign Worker Program."21

Currently, these women (mostly women of colour) subsidize our economy by providing time and energy for many Canadian women to participate in the labour force at higher rates of pay. The care-givers in some sense liberate Canadian women (and men) to participate in their communities and to volunteer their time if they so choose. They doso at a very high price, however: most domestic care-givers forfeit their own professional training and postsecondary education to gain experience as a care-giver and learn English working for an employer in Singapore or Hong Kong, so that they can qualify for the current Canadian program. Under the Review, they would not have access to permanent residence and citizenship, but be confined to the temporary worker stream. It becomes a moot point that if domestic care-givers were included in the permanent resident stream, would they might still be excluded from citizenship, based on the active participation requirement in which two of four criteria outlined above must bemet. Women paid tolook after other people's children, and to clean and cook in someone else's home are unlikely to have much time for volunteer community work, a second job, or full-time study. Marginalized not only by their gender and cultural markings, these women would be short-changed on the basis of their non-immigrant status.

In the absence of other options, simply to eliminate this program without careful reexamination would be to eliminate the one racialized and gendered stream of Canadian immigration without further discussion. In their own words, these women are "the Third World in our living rooms." 22 They happen to be well-educated, employable, and competent in an official language too. To relegate them to temporary migrant status with no future in Canada is to cut out the pay off for the sacrifice many of these womenmake. The point is not simply, however, to preserve the current system of allowing domestic workers to come to Canada and then become landed immigrants, but rather to point out that the very groups that the $I L R$ wants to include under the rubric of "modern pioneers" tend to excludepeople of colour, in this case women.

\section{Designer Immigrants Only?}

Responding to charges that the language proficiency requirement is racist, Susan Davis, a co-author of the Review said that "[i]t's not that we want designer immigrants, it's not that we want them from English-speaking countries only." ${ }^{23}$ Nonetheless, it is clear from this short analysis that such requirements will weed out some women and people in non-English or non-French-speaking countries from the proposed self-supporting class. The recommended requirements of citizenship, namely employment, study, family care, and community participation; may also have an adverse impact for women who-despitegreatstrides-remain the primary care-givers in families and are also responsible for most of the unpaid domestic work.

While the Review calls for "modern pioneers" to come to Canada to generate prosperity, stability, competitiveness, new technology; and global investment (chapter 6,6.3), the notion of postmodern pioneers is perhaps more apt. These pioneer immigrants would be knowledge 
workers, armed with a job offer and/or experience in high-end services upon arrival in Canada. They would be at ease moving between cultures and airports in the increasingly borderless world economy. The family class of immigration would remain largely intact and would provide a substantial stream of newcomers to Canada as long as they could speak an official language or finance their own tutoring. The less fortunate temporary foreign workers - with a smaller chance of qualifying-would create a transnational migrant circuit of short-term employees from various locations.

Left in their wake are what I see as the modern, now outdated, pioneers, namely refugees, whose entry is ensured through government-sponsored international agreements growing out of World WarII. Accepted grudgingly as part of international legal agreements and humanitarian obligation, these modern pioneers find themselves outside the circulation of voluntary migration on a global scale. They are wards of theincreasingly outdated, state-centric system of what is now global political economy. If implemented, the Review's recommendations would separate selfsupporting immigrants and their families from refugee immigrants more than ever before: the cosmopolitan postmodern immigrant would have little, if anything, in common with the newly arrived refugee who participates in a much more marginal economy of international displacement and migration.

\section{Concluding Comments}

The existence of two very different regimes for the circulation of capital and the circulation of immigrants, as well as two equally different regimes for the protection of human rights and the protection of state sovereignty, poses problems that cannot be solved by the old rules of the game. ${ }^{24}$

It is no surprise that sovereignty is increasingly decentred and the territory of states like Canada partially denationalized. Nonetheless, it is largely a domestic issue that is at the base of current discussion of immigration. At the heart of immigration debate is the reality that the federal government sets legislation and policy, but does not assume much financial responsibility for the settlement and integration of newcomers. This is an intractable problem, but the proposals of the ILR donot represent the best solution.

If implemented, the proposals outlined in the Review will create a two-tier system of immigration to Canada: on the one hand, a wave of highly qualified immigrants who are more likely to be male than female given the prerequisite education, language, and skilled employment experience; and on the other, a small marginal group of refugees which will not be assessed on their "ability to establish," but will be chosen from embassies and consulates overseas, rather than accepted from ports of entry here in Canada. This distinction between the best and brightest versus the vulnerable and deserving could not be more starkly drawn.

The ILR in this connection proposes very gendered streams of masculine expertise and feminized need. Self-supporting immigrants and their families will be worth Canada's while, whereas the handful of refugees accepted for resettlement will be worthy of Canada's shrinking humanitarian hospitality. The least desirable group is that which is not chosen by either Canadian immigration authorities nor designated employers, namely refugee claimants. Refugees should be helped as close to home as possible, says the Review, where they are-inmyestimation - noburden to the Canadian economy nor to the taxpayer.

\section{Notes}

1. Saskia Sassen, Losing Control? (New York: Columbia University Press, 1996), 25.

2. CIC, 1996 cited in Virginia Galt, "Language Barrier: Racist or Realistic?" The Globe and Mail, 20 January 1998. Englishspeaking immigrants $52 \%$, French-speaking 4\%, both English and French $3 \%$; neither language $41 \%$.

3. CCR, "Immigration Legislative Review and Refugee Women," issued by the CCRGender Issues Core Group, 4 February 1998.
4. For BC ESL students, the province paid “about $\$ 70$ million" annually. See, Editorial, The Vancouver Sun, 27 February 1998).

5. Editorial, Toronto Star, 2 March 1998.

6. Virginia Galt, "Language Barrier: Racist or Realistic?"

7. Nancy Fraser, Justice Interruptus (New York/London: Routledge, 1997); see also "Women, Welfare and Politics," in Unruly Practices (Minneapolis: University of Minnesota Press, 1989).

8. Citizenship and Immigration Minister Lucienne Robillard made her point regarding fraudulent in a recent report to a House of Commons committee ("Grit Tough on Aliens, More Getting the Boot: Minister," Globe and Mail, 30 April 1998). She noted that the deportation of illegal immigrants and refugees is up 36.5 percent in 1997 as compared to 1996 ; "4,800 bogus refugees go the boot, an increase of more than $95 \%$."

9. Bruce Cheadle, "UNHCR pans some proposed changes to Canadian refugee system," The Vancouver Sun, 18 April 1998.

10. Bill Frelick, "Preventing Refugee Flows: Protection or Peril," in World Refugee Survey 1993 (Washington, DC: USCommittee for Refugees, 1993); UNHCR, The State of the World's Refugees: A Humanitarian Agenda (Oxford/New York: Oxford University Press, 1997).

11. I am grateful to Dan Hiebert for this particular phrasing of the issue.

12. Wenona Giles, "Aid Recipients or Citizens?: Canada's Role in Managing the Gender Relations of Forced Migration," in Development and Diaspora: The Gender Relations of Refugee Experience, edited by W. Giles, H. Moussa, and P. Van Esterik (Dundas, ON: Artemis Enterprises, 1996).

13. RosalynKunin, "A Discussion of the Immigration Legislative Review: Not Just Numbers: A Canadian Framework for Future Immigration" presentation to the Research on Immigration and Integration in the Metropolis Project, Vancouver, 17 March 1998.

14. This information was provided by $C C R$ based on CIC statistics in CCR listserve communication April 23, 1998 issued by Janet Dench.

15. Sources: U.S. Department of State, Department of Justice, and Department of Health \& Human Services "Report to the Congress on Proposed Refugee Admissions for Fiscal Year 1996," July 1995. Pre-publication copy; "Report to the Congress on Proposed Refugee Admissions for Fiscal Year 1995," September 1994; most recent numbers are taken from the State Department web site at <http://www.state.gov/www/global/prm/FY97refugees.html>. Canadian 
totals are announced every November 1st; they corne from Citizenship and Immigration Canada and were confirmed for the purpose of this table by the Immigrant Services Society of British Columbia.

16. Saskia Sassen, Losing Control?, 59.

17. Saskia Sassen, Losing Control?, 86.

18. CCR, "Immigration Legislative Review and Refugee Women," issued by the CCR Gender Issues Core Group, 4 February 1998.

19. Marie Boti and Sr. Florchita Bautista (directors), Brown Women, Blonde Babies, (Mon treal: Productions Multi -Monde /Le Videographie; Vancouver, B.C.: Idera Films [distributor], 1991).

20. See recommendation 50 .

21. See recommendation 75 .

22. Marie Boti and Sr. Florchita Bautista (directors), Brown Women, Blonde Babies.

23. Susan Davis cited in Virginia Galt, "Language Barrier: Racist or Realistic?"

24. Saskia Sassen, Losing Control?, xvi. o

\section{Breaking Ground:}

\section{The 1956 Hungarian Immigration to Canada}

\author{
Edited by Robert $\mathrm{H}$. Keyserlingk \\ Toronto: York Lanes Press, 1993; ISBN 1-55014-232-1; \\ 117 pages, $\$ 6.99$
}

This book is a collection of personal and archival-based memories on the selection, transport and settlement of about 40,000 Hungarian refugees in Canada in one year. It is a source of primary record as well as scholarly reflection on one of the most significant refugee movements to Canada after World War II-the 1956 Hungarian refugee movement.

Based on papers that were presented at a 1990 conference, the authors touch on the unique political, administrative and settlement features of this movement. The resulting work, edited by Professor Keyserlingk, is a unique mix of personal reminiscences and academic scholarship.

\section{Available from:}

Centre for Refugee Studies

\section{Legitimate and Illegitimate Discrimination: New Issues in Migration}

\section{Edited by Howard Adelman}

\section{Toronto: York Lanes Press, 1995; ISBN 1-55014-238-0; 287 pages, indexed; \$22.95}

Freedom of movement: If the members of a state are forced to flee, the legitimacy of that government is questionable. On the other hand, if members cannot or must leave, again the government is not democratically legitimate.

Immigration control: While limiting access and determining who may or may not become members of a sovereign state remains a legitimate prerogative of the state, the criteria, rules and processes for doing so must be compatible with its character as a democratic state.

Legitimate and Illegitimate Discrimination: New Issues in Migration, edited by Professor Howard Adelman, deals with the question of legitimacy with cases studies from the Developing World, Europe, Australia, the United States, and Canada.

\section{CONTRIBUTORS:}

Rainer Bauböck, Howard Adelman, Gaim Kibreab, A. Essuman-Johnson, Grant M. Farr, Lawrence Lam, Oscar Schiappa-Pietra, Tomas Hammar, Frédéric Tiberghien (in French), Lois Foster, and Arthur C. Helton.

$$
\text { Available from: }
$$

Centre for Refugee Studies

Fax: (416) 736-5837 • Email: refuge@yorku.ca 